\title{
Consumption at the Bottom of the Pyramid: Current State of Research and Suggestions for Future Study
}

\section{Alyce Cardoso Campos}

Universidade Federal de Lavras, Brazil | alycecardosoc@ yahoo.com.br

\section{Daniel Carvalho de Rezende}

Universidade Federal de Lavras, Brazil | rezendedc@gmail.com

\section{José Willer do Prado}

Universidade Federal de Lavras, Brazil |jwprado@gmail.com

\section{Thaísa Barcellos Pinheiro do Nascimento}

Universidade Federal de Lavras, Brazil | thaisapinheiro35@ gmail.com

\section{Humberto Rodrigues Marques}

Universidade Federal de Lavras, Brazil | hbetorm@hotmail.com

\section{André Grutzmann}

Universidade Federal de Lavras, Brazil | andregrutzmann@ gmail.com

Volume 10 No 1 (2020) ｜ ISSN 2158-8708 (online) ｜ DOI 10.5195/emaj.2020.192 | http://emaj.pitt.edu Abstract

This article reviews the state of the literature on consumption at the bottom of the pyramid and summarizes the studies' suggestions for future research. This study was conducted using data from the Web of Science and Scopus databases with the help of CiteSpace and CitNetExplorer 1.0.0. This research is justified due to: (a) absence of a broad systematization of the theme; (b) contribution and encouragement of new researchers to take part in studies on the subject; and (c) indication of a broad international literature that can encourage studies on consumption at the base of the pyramid.

Keywords: Bottom of the Pyramid, Low Income, Consumption, Market, Future Research

\section{$(\mathrm{cc}) \mathrm{Br}$}

New articles in this journal are licensed under a Creative Commons Attribution 3.0 United States License.

\section{ULLS D- $\underline{\operatorname{sen} R}$}

This journal is published by the University Library System of the University of Pittsburgh as part of its D-Scribe Digital Publishing Program, and is cosponsored by the University of Pittsburgh Press. 


\section{Consumption at the Bottom of the Pyramid: Current State of Research and Suggestions for Future Study}

\author{
Alyce Cardoso Campos \\ Daniel Carvalho de Rezende
}

José Willer do Prado

Thaísa Barcellos Pinheiro do
Nascimento

Humberto Rodrigues Marques

André Grutzmann

\section{Introduction}

Interest in research on the behavior of lowincome consumers has grown since Prahalad's studies on the consumption potential at the bottom of the pyramid in the early 2000s (Prahalad and Hart, 2002; Prahalad and Hammond, 2002). The term, bottom of the pyramid $(\mathrm{BoP})$, was coined to refer to people with low purchasing power. Although this topic received increased attention in the early 2000 s, the concept's real impact began to gain strength in 2007 when the number of publications about the topic grew significantly (Kolk et al., 2014). One of the most frequently cited studies in this literature is Prahalad's book "The Fortune at the Bottom of the Pyramid" (2005). In that study, the author defends doing business in poorer markets and identifies examples of good investments in a large underexplored sector. As markets at the top of the pyramid become saturated, an opportunity for profit and growth appears in the large number of poor people who make up the bottom of the pyramid (Cooney and Shanks, 2010).

Recent years have seen considerable economic growth, and new approaches to reducing poverty have appeared (Cooney and Shanks, 2010). Nevertheless, the poor still have limited participation in the consumer society. Studies on business initiatives at the bottom of the pyramid are still rare. Despite the large population belonging to the $\mathrm{BoP}$, companies continue to target their products and services to higher classes. Research also takes a similar course, neglecting this large market segment.

Consumers at the bottom of the pyramid are overloaded with low-quality products and lack goods that actually meet their needs. Furthermore, the poor are seen in a more dignified light when they are perceived as consumers rather than as recipients of aid or donations. They therefore resort to consumption as a way to feel respected. These and other reasons support arguments for investing in businesses at the $\mathrm{BoP}$ as a way to make a profit while also helping to alleviate poverty and raising the living standard of this population.

The main motivation for this study is to further advance academic knowledge about the population at the bottom of the pyramid. That market segment is sizable, relevant and important to the economic and social development. A research that connects those individuals to consumption and provide information to marketing researchers and society is desirable.

Based on the research by Filser et al. (2017), this study reviews the literature on consumption at the bottom of the pyramid and summarizes suggestions for future research found in articles published in (2017) in order to collaborate with future research on the topic. This research is justified due to: (a) absence of a broad systematization of the theme; (b) contribution and encouragement of new researchers to take part in studies on the subject; and (c) indication of a broad international literature that can encourage studies on consumption at the base of the pyramid.

The introduction part is followed by a section that addresses what has been studied about the bottom of the pyramid and analyzes reviews of the literature on the topic. The methodology section describes the steps taken to conduct the review. Next, the results are presented, showing the volume of publications, the most frequently cited articles in the sample, the journals with the greatest number of publications in the field, a map of the world showing the number of publications per country, the keywords most frequently cited over time, a network of the most cited articles in the selection and a table summarizing suggestions for future research composed by authors published in 2017. Finally, the conclusions and references used to conduct the review are presented.

\section{Literature Review}

Agarwal et al. (2017) argue that, in the last two decades there has been progress in innovation processes carried out with special focus at the base of the pyramid. However, the literature in this field resulted in a variety of approaches to innovation, leading to a fragmented literature and confusion with regard to terminology. The authors therefore undertook a systematic review of the literature for the purpose of organizing the study of approaches to innovation that arose from emerging markets. The literature was examined according to the methodologies used, current trends, research outcomes and industrial and geographic focus. The authors' analysis found a growing standardization of the use of terminology and increasing emphasis on "bottom-up" and structured approaches to innovation. The results showed significant applications of the innovations beyond emerging markets to wider markets and instigate further studies (Agarwal et al., 2017).

In 2014, Kolk, Rivera-Santos and Rufín conducted a systematic review aimed at determining what happened to the bottom of the pyramid concept since it was introduced by Prahalad in 1999. The review found 104 articles published in journals over a ten-year period (2000-2009) and concluded that the concept developed radically from Prahalad's original form for 
multinational companies. Over the course of ten years, a more complex scenario emerged, with large variations in the terms, initiatives and impacts of the concept of the bottom of the pyramid. The study identifies gaps in the literature and makes suggestions for future research (Kolk et al., 2014).

In 2008, Rocha and Silva reviewed studies conducted in Brazil on consumption by the poor and grouped the results into five categories. The first was family spending, which was divided into five groups: Those who suffer from rent, the Brazilian "way of getting by," valorization of having possessions and those who struggle to survive and investors. The second was the use of credit, identifying aspects such as credit as inverted savings and anticipated consumption, credit as a means of budget control, credit as a means of distinguishing oneself and credit as a gift. It also found that, informal credit is more commonly used than formal credit among lower-income people. The third category was brand choice, which serves as a sign of quality and social hierarchy, distinguishing between name-brand and offbrand products, as well as "rich-man" and "poor-man" brands. It also includes strategies for brand consumption, with more prestigious brands being more widely used. The fourth category was choice of store, which, for lowincome consumers, constitutes an important space that can arouse emotions ranging from joy and pleasure to embarrassment and humiliation (Rocha and Silva, 2008).

The final category was the meaning of having possessions, including housing as a central element in a family's possessions, electronics as a sign of modernity and prosperity, household appliances as a sign of distinction, furniture as the house's dressing, clothing as a sort of camouflage or a symbol of distinction, and food as also playing an important symbolic role. The authors then analyze ways companies can act in this low-income segment, providing examples of creative ways that have proven successful in Brazil. They also propose a research agenda related to consumption by low-income individuals and marketing directed toward them (Rocha and Silva, 2008).

\section{Data and Methodology}

To achieve its objective, the study employed a bibliometric research method, which has proven to be a great ally of researchers, providing the state of the art in various knowledge fields (Nogami and Pacagnan, 2011; Bojović et al., 2014). Studies in the bibliometry and scientometry field are mainly focused on measuring and classifying scientific production on a particular topic (Hayashi, 2013).

However, some commonly occurring limitations of this method are polysemy (multiplicity of word meanings), errors in data collection, and a superficial view of the field of study (Bittar et al., 2011; Taşkın and Al, 2014). To minimize these and other problems that can occur during the study, a research framework was used, as recommended by Prado et al. (2016), adjusted to sources from two databases, and mapping of future research as proposed by Chen and $\mathrm{Wu}$ (2017) and Filser et al. (2017), as shown in Figure 1.

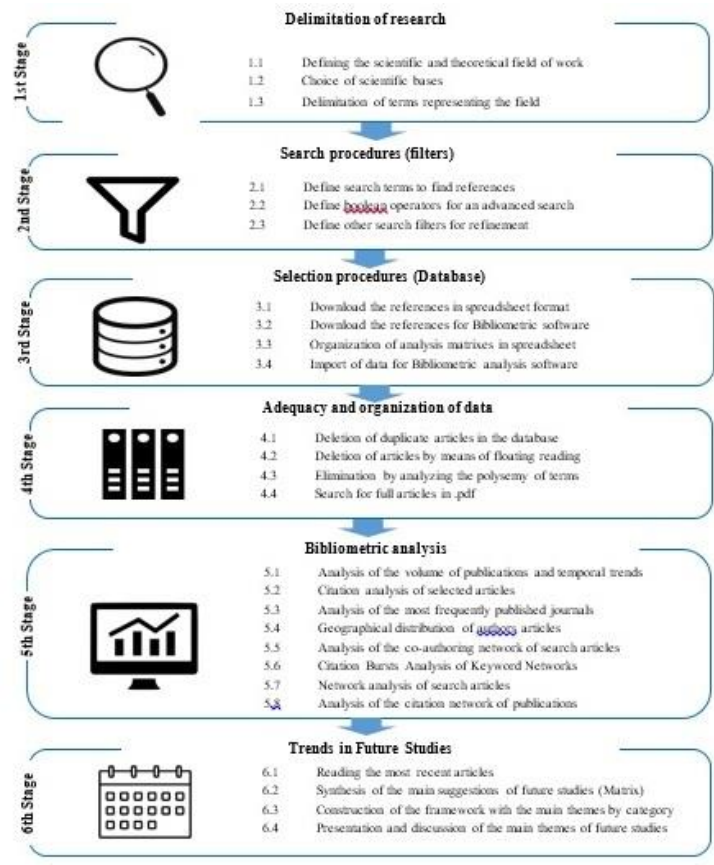

Figure 1. Research Framework

Source: Prado et al. (2016)

Following the research framework in Step 1, the theme was defined as studies on the market and consumption at the bottom of the pyramid. Web of Science and Scopus were selected as suggested by Filser et al. (2017). In Step 2, to minimize the difference between the two databases, the search procedures were defined to use the fields "Article title, Abstract and Keywords" for Scopus and "Topic" for WoS, which include the article title, abstract, and the keywords author as well as Keywords Plus, as defined below:

WoS: $\quad$ TS =(bottom_of_the_pyramid OR bottom_of_pyramid) AND TS=(consum* OR market*)

Scopus: TITLE-ABS-KEY (bottom_of the pyramid OR bottom_of_pyramid) AND TITLE-ABS-KEY (consum* OR market*)

The searches were conducted in August 28, 2018 , in the international databases Web of Science and Scopus. The search was also filtered by article to standardize the type of document. Some Boolean operators such as "OR" and "AND" were also used to add the results of all terms, thus ensuring a greater number of articles focused on consumption or the market at the BoP.

In Step 3, regarding the procedures for data selection and importing, Microsoft Excel, CiteSpace (Chen, 2004, 2006), CitNetExplorer 1.0.0 (Van Eck and Walman, 2014) and Google Fusion Tables were chosen. Step 4 allowed organizing the downloaded bibliographic data. In Step 5, bibliometric analyses were undertaken to review and consolidate information about research on the BoP.

In Step 6, a framework was created for the Trends in Future Studies based on the recommendations 
for future research found in articles about the BoP in the year (2017), as suggested by Filser et al. (2017).

\section{Results}

The Venn diagram in Figure 2 shows the number of articles about consumption at the bottom of the pyramid in Scopus, Web of Science and both. More articles appeared in Scopus $(\mathrm{n}=223)$ than those in Web of Science $(n=139)$. After excluding the 167 articles found in both databases, a total of 254 unique articles were identified. Although there is considerable overlap, many articles appeared only in one database: 115 appeared only in Scopus, while 31 appeared only in WoS. This means that, a search of only Scopus would have missed $12.2 \%$ of the articles, while a search of only WoS would have missed $45.28 \%$ of the articles.

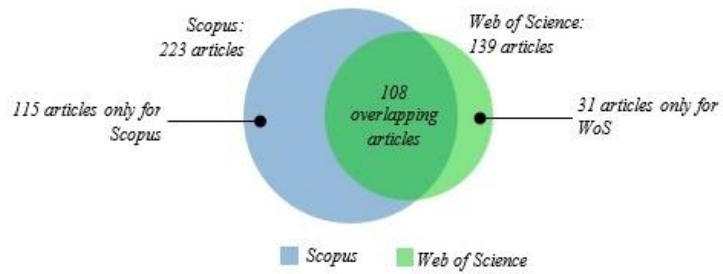

Figure 2. Articles about BoP in the Scopus and Web of Science Databases

Figure 3 shows publications by year in the sample analyzed. The first publication to appear in WoS and Scopus is "Case Study: Hindustan Lever Limited and marketing to the poorest of the poor," by Ahmad, Gorman and Werhane in 2004 (Ahmad et al., 2004). This study addresses marketing activities in the 1970s, in which Hindustan Lever Limited (a subsidiary of Unilever in India) remained focused on the middle class and urban elite, while an Indian entrepreneur produced and marketed Nirma detergent to the poor rural sector. Nirma became the second-best-selling brand in the country in 1997, causing analysts to rethink their perception that the bottom of the pyramid as of no interest.

Articles that were older but nevertheless significant in the field, such as Prahalad and Hart (2002) and Prahalad and Hammond (2002), were not included in the sample. This exclusion occurred because the first did not appear in either of the databases used, and the second contained no abstract and its title does not mention the bottom of the pyramid.

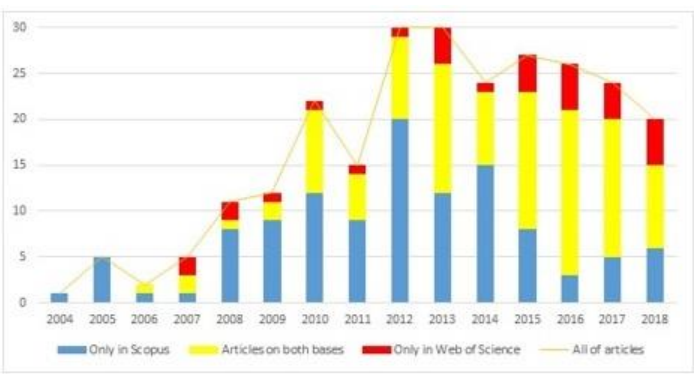

Figure 3. BoP Literature Development based on Data from Scopus and Web of Science
In 2012 and 2013, there was a significant increase in the volume of publications, with 30 publications in each of these years, a number that remained practically steady with little variation in subsequent years. Since the search was conducted before the end of 2018, it cannot be stated there was a decline in publications.

Table 1 shows the frequently cited articles on the topic in the Web of Science and Scopus. The ten frequently cited studies in each database were selected, leaving a total of 15 articles after duplicates were excluded.

The most frequently cited article was Karnani (2007), "The mirage of marketing to the bottom of the pyramid: How the private sector can help alleviate poverty," with 329 citations in Scopus and 265 in WoS. The author argues that, large companies can reap large profits at the bottom of the pyramid while simultaneously helping eradicate poverty by seeing the poor as producers and giving preference to the products they sell rather than trying to sell something to them.

Table 1: Most Frequently Cited Articles in the Literature on BoP in Scopus and Web of Science

\begin{tabular}{|c|c|c|c|c|c|}
\hline & Tiste & Auchors & Jourusle (ISSN) & $\begin{array}{l}\text { Citabions } \\
\text { Scopas wo }\end{array}$ & $\begin{array}{l}\text { Giatious per year } \\
\text { - Scoper o WoS }\end{array}$ \\
\hline & 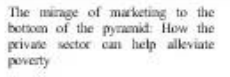 & $\begin{array}{l}\text { Kannevi } \\
(2007)\end{array}$ & $\begin{array}{l}\text { Califfinat managemex } \\
\text { reviex (2162-8564) }\end{array}$ & $320 \quad 260$ & \\
\hline & 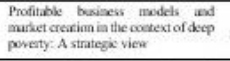 & $\begin{array}{l}\text { Scelos and } \\
\text { Mair (200m) }\end{array}$ & 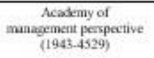 & 202 & \\
\hline & 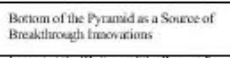 & $\begin{array}{l}\text { Prualuhad } \\
(2012)\end{array}$ & 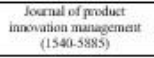 & $127 \quad 100$ & \\
\hline & 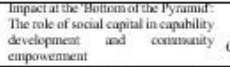 & 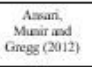 & 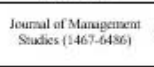 & 115 & \\
\hline & 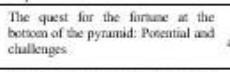 & 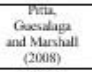 & 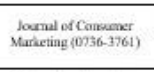 & 80 & \\
\hline & 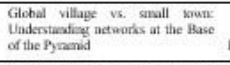 & 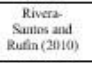 & 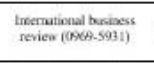 & 75 & \\
\hline & 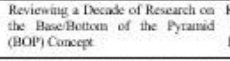 & 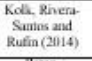 & $\begin{array}{l}\text { Business \& Sociaty } \\
\text { (1552-42015) }\end{array}$ & - & \\
\hline & 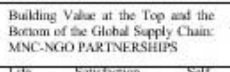 & $\begin{array}{c}\text { Prece- } \\
\text { Alemun and } \\
\text { Sandilands } \\
\text { (2018) } \\
\end{array}$ & $\begin{array}{l}\text { Califinzia manageneat } \\
\text { reviex (2162-8564) }\end{array}$ & - & \\
\hline & 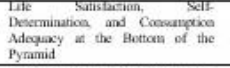 & $\begin{array}{l}\text { Marrin and } \\
\text { Hall (2012) }\end{array}$ & 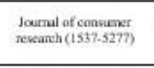 & 71 & s. \\
\hline & 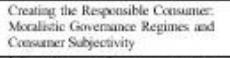 & 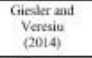 & $\begin{array}{l}\text { Joumal of cansuner } \\
\text { reckanch (1537-5277) }\end{array}$ & 6956 & \\
\hline & 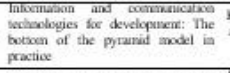 & 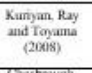 & $\begin{array}{l}\text { Indinuation Sockity } \\
\text { (1087-6537) }\end{array}$ & 67 & \\
\hline & 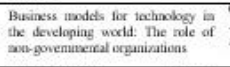 & 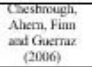 & $\begin{array}{l}\text { Calfinsia managemet } \\
\text { reviea (2162-8564) }\end{array}$ & as & \\
\hline & 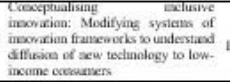 & $\begin{array}{l}\text { Foster ind } \\
\text { Hectis (2013) }\end{array}$ & 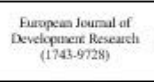 & 63 & 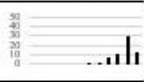 \\
\hline & 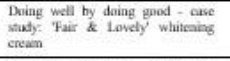 & $\begin{array}{l}\text { Kamani } \\
(2007)\end{array}$ & 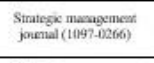 & - & \\
\hline & 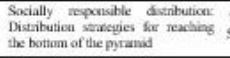 & $\begin{array}{l}\text { Vachani and } \\
\text { Smith (2008) }\end{array}$ & $\begin{array}{l}\text { Califonzu managemet } \\
\text { revier (2162-8564) }\end{array}$ & & \\
\hline
\end{tabular}

The article that received the second largest number of citations was "Profitable business models and market creation in the context of deep poverty: A strategic view," by Seelos and Mair (2007), which was found only in Web of Science. This work discusses how businesses can grow profitably in the BoP segment if they know how to rethink their strategies and business models to involve new resources and local partnerships, thereby creating new markets that include the poor. However, it claims that the literature says nothing about how to implement this. 
Prahalad is one of the leading authors on this topic. One of his articles ranks among the most frequently cited in the sample: "Bottom of the Pyramid as a Source of Breakthrough Innovations" (Prahalad, 2012). In this study, the authors recognize BoP markets as a new source of radical innovation, stating that global companies are increasingly applying innovations at the bottom of the pyramid to developed markets.

Ansari, Munir and Gregg's article "Impact at the 'Bottom of the Pyramid': The role of social capital in capability development and community empowerment" (2012), which is only found in the Scopus database, adopts a more community-centered and socially integrated approach to the bottom of the pyramid. It states that alleviating poverty is not limited to increasing income, ignoring critical questions of ethical, social and political significance. The authors present a structure to gain a better understanding of the impact of businesses at the bottom of the pyramid, in which businesses engage the BoP and other organizations to build social capital and improve resources.

As seen, the articles focus on how to alleviate poverty while making a profit for businesses. Pitta, Guesalaga and Marshall's article "The quest for the fortune at the bottom of the pyramid: Potential and Challenges" (2008) also discusses this subject by providing guidance about how companies need to adapt their marketing strategies to sell to the BoP market and what type of partnerships should be forged to achieve success

Table 2 shows the journals with the greatest number of publications in the databases used in the sample. The most prominent are the Journal of Consumer Marketing and Marketing Theory, with 12 and seven publications, respectively.

Table 2: Journals with the Most Articles published in the Scopus and Web of Science Databases

\begin{tabular}{|c|c|c|c|c|c|}
\hline Journals & Frequency & Rate & ISSN & $\begin{array}{l}\text { JCR (2017) } \\
\text { WoS }\end{array}$ & $\begin{array}{c}\text { Cite Score } \\
\text { (2017) } \\
\text { Scopus }\end{array}$ \\
\hline $\begin{array}{l}\text { Joumal of Consumer Marketing } \\
\text { Marketing Theory }\end{array}$ & $\begin{array}{l}12 \\
7\end{array}$ & $\begin{array}{l}4.72 \% \\
2.76 \%\end{array}$ & $\begin{array}{l}0736-3761 \\
1741-301 \mathrm{X}\end{array}$ & & $\begin{array}{l}1.71 \\
2.74\end{array}$ \\
\hline $\begin{array}{l}\text { Marketing Ineory } \\
\text { Califomian Mangement Review }\end{array}$ & 5 & $1.97 \%$ & $2162-8564$ & $\begin{array}{l}3.3002 \\
3.302\end{array}$ & 4.28 \\
\hline $\begin{array}{l}\text { Joumal of Business Ethics } \\
\text { Technologicical Forecasting and Social Change }\end{array}$ & & $1.97 \%$ & $\begin{array}{l}1573-0697 \\
0040-1625\end{array}$ & 2.917 & 2.91 \\
\hline $\begin{array}{l}\text { Teehnologicalal orecasting and Social Change } \\
\text { Intemational Journal of Business and Globalisation }\end{array}$ & $\frac{5}{4}$ & $\begin{array}{l}1.97 \% \\
1.57 \%\end{array}$ & $\begin{array}{l}0.040-1625 \\
1753-33635\end{array}$ & 3.129 & 3.42 \\
\hline Joumal of Business Ethics & & $1.57 \%$ & $0148-2963$ & & $\begin{array}{l}0.75 \\
3.31\end{array}$ \\
\hline Journal of Public Policy and Marketing & 4 & $1.57 \%$ & 1547.7207 & 2.179 & 2.43 \\
\hline Marketing Intelligence and Planning & 4 & $1.57 \%$ & $0263-4503$ & 1.421 & 1.71 \\
\hline $\begin{array}{l}\text { Partial } \\
\text { OOther joi }\end{array}$ & 50 & $\frac{19.69 \%}{803 \%}$ & Mean & JCR & $\begin{array}{l}\text { Cite } \\
\text { Sccore }\end{array}$ \\
\hline Other jo & 204 & $80.31 \%$ & & 2560 & \\
\hline
\end{tabular}

The Journal of Consumer Marketing (JCM) publishes studies that provide information about the consumer behavior throughout the world, as consumption is a key element to knowledge of human behavior and understanding consumer behavior as a key to creating marketing strategies. These studies therefore examine the theoretical and managerial implications of such behavior. This journal publishes not only research, but also case studies and commentary and covers both theory and practice. One of the most cited articles, "The quest for the fortune at the bottom of the pyramid: Potential and challenges" (Pitta et al., 2008) appears in this journal.

Marketing Theory provides a high-quality specialized channel for social and management scientists involved in developing and reformulating marketing as an academic discipline, conducting a critical analysis of existing theory. It covers the full range of theoretical and methodological debates, including consumer behavior, strategy, development of new products and others. The journal is not limited to specific fields, but covers the full range of marketing issues.

California Management Review is highly relevant to this field, having published four of the 15 most frequently cited articles in the sample, including the most commonly cited study: "The mirage of marketing to the bottom of the pyramid: How the private sector can help alleviate poverty" (Karnani, 2007).

Figure 4 shows the geographical distribution of authors by institutions that conduct BoP research. The leading institutions in terms of the number of publications are located in the United States, United Kingdom, India and Australia. These countries appear in warm colors (red) on the map. According to the Web of Science, the United States accounts for 47 articles, the United Kingdom for 27, India for 23 and Australia for 11. According to Scopus, the United States accounts for 67 articles, India for 38, the United Kingdom for 36 and Australia for 24.

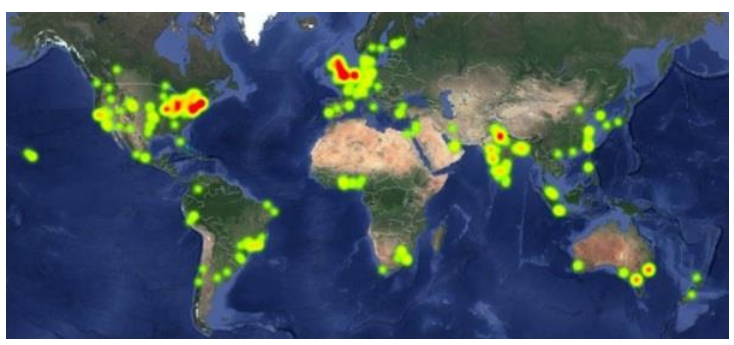

Figure 4. Geographical Distribution of BoP Researchers

The first publication in the United States was Ahmad, Gorman and Werhane's article (2004) "Case Study: Hindustan Lever Limited and marketing to the poorest of the poor," which focused on Nirma detergent, produced by an Indian entrepreneur who marketed to the rural low-income sector, while other leading brands remained focused on the middle and upper classes. Within a few years, Nirma detergent became the country's second-best-selling brand. The article suggests that, this product can serve as an example and help identify opportunities to serve the bottom of the pyramid. The most frequently cited study from the United States was Karnani's critique of Prahalad's idea, "The mirage of marketing to the bottom of the pyramid: How the private sector can help alleviate poverty." In this study, the author shows that, it is a dangerous illusion to think that one can make a profit and eradicate poverty by selling to the poor. The solution is to view the poor as producers rather than as consumers.

The first publication in the United Kingdom was Blake's (2006) "From protection to innovation: BT's journey in corporate social responsibility," which presents a study of corporate social responsibility by the British telecommunications giant BT, describing how it not only takes steps to reduce greenhouse gas emissions, but also creates new products and services for the BoP, helping to reduce poverty. The most frequently cited article from the United Kingdom, Ansari et al. (2012) "Impact at the 'Bottom of the Pyramid': The role of social capital in capability development and community empowerment," presents a more community-centered 
and socially integrated approach to the bottom of the pyramid. It redefines poverty as constituting not only a lack of income, but also a lack of abilities that can be developed.

India's first publication was the article "Study of the principles of innovation for the BoP consumer The case of a rural water filter" (Prasad and Ganvir, 2005). It discusses differences in the principles of innovation for markets at the base and the top of the pyramid, taking as an example the development of a household water filter for the rural population in India and leading to a significant reduction in the number of water-transmitted diseases. The most frequently cited article from India was "Information and communication technologies for development: The bottom of the pyramid model in practice" (Kuriyan et al., 2008), which examined the Akshaya project, an information services franchise in India that promotes both financial viability and social development through access to computers.

As Figure 4 also shows, this survey of the WoS identified a total of 209 research organizations worldwide involving in studies on the bottom of the pyramid in the period of 2004 to 2018. The leading institutions include the Indian Institute of Management Calcutta (with six articles, 57 citations and h-index of 5), Lancaster University (six articles, 22 citations and hindex of 3) and the University of London (six articles, 66 citations and h-index of 3). According to Scopus, there are 160 such institutions. The leading ones include Western Sydney University (with seven articles), Swinburne University of Technology (with seven articles) and the Indian Institute of Management Calcutta (with six articles).

The Indian Institute of Management Calcutta has six articles in Scopus and six in Web of Science, with only three articles listed in both databases, for a total of nine articles, making it the institution with the greatest involvement in research on the bottom of the pyramid in the analyzed sample.

Figure 5 analyzes the co-authorship network of articles in the search. Some of the most significant relationships among the networks will be discussed below. A network with seven authors appears at the top of the figure. It consists of Ahmed M., Ozaki A., Ozaki A., Ogata K., Ito S., Miyajima I., Ahmed A., and Okayasu T. They worked together on the article "Poor farmer, entrepreneurs and ICT relation in production and marketing of quality vegetables in Bangladesh." They are all associated with Kyushu University, located in Fukuoka, Japan, as professors, associate professors and assistant professors. They are members of the Institute of Tropical Agriculture, Advanced Information and Communication Technology, Bioproduction Environmental Sciences and the Department of Mechanical Engineering.

Next, there are several central authors on the networks with six, five or three authors, namely, Saren M., Singh R. and Gupta S., respectively. Saren M. carried out the work "A qualitative enquiry into the appropriation of mobile telephony at the bottom of the pyramid" together with Binsardi B. and Prendergast R. and the article "Co-creation of value at the bottom of the pyramid: Analysing Bangladeshi farmers' use of mobile telephony" with Bhowmick S., Pandit A. e WoodruffeBurton H. Mike Saren is a marketing professor in the
School of Business at University of Leicester, Leicester, UK. Ben Binsardi is from Glyndwr University, Wrexham, UK, Renee Prendergast belongs to Queen's University Belfast, Belfast, UK, Sanjay Bhowmick is from Northumbria University Newcastle upon Tyne, UK, Helen Woodruffe-Burton is a professor at Edge Hill University, Ormskirk, UK and, lastly, the only author who is not from the United Kingdom, Ameet Pandit, a professor at the University of Newcastle, Newcastle, Australia.

Ramendra Singh conducted two studies with Monideepa Tarafdar and Prashanth Anekal, "Impact of ICT-enabled product and process innovations at the Bottom of the Pyramid: a market separations perspective" and "Market development at the bottom of the pyramid: examining the role of information and communication technologies." Ramendra Singh is an assistant professor focusing on marketing at the Indian Institute of Management Calcutta, Kolkata, India; Monideepa Tarafdar is a professor at Lancaster University, Lancaster, UK; and Prashanth Anekal is an assistant professor at Saginaw Valley State University, University Center, Michigan, USA. Ramendra Singh also conducted a study with Katy Mason and Ronika Chakrabarti, forming the other connection in the figure. Katy Mason and Ronika Chakrabarti are professors in the Department of Marketing at Lancaster University in Lancaster, UK.

The network shown in purple consists of Ashish Kumar, Ravi Shankar, Kirankumar S. Momaya and Sandeep Gupte, the four co-authors of "The market for wireless electricity: The case of India." Ashish Kumar works for Nokia, in Espoo, Finland and is interested in business, management, strategic management and marketing management. Ravi Shankar is at the Indian Institute of Technology Delhi, New Delhi, India. Kirankumar S. Momaya is a professor at the Indian Institute of Technology Bombay, Mumbai, India and Sandeep Gupte works at Indus Towers, in Gurgaon, India.

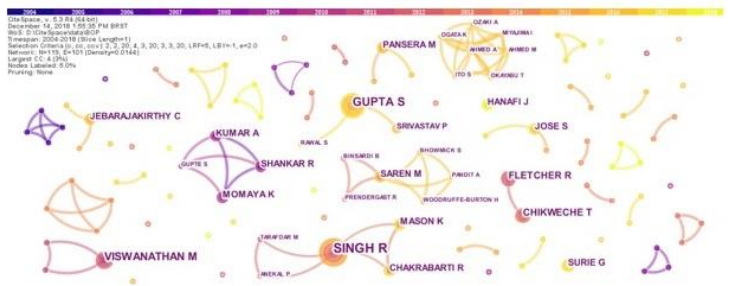

Figure 5. Network of co-authorship of the articles in the search (frequency $>=2$ )

Shruti Gupta worked with Pratish Srivastav in the articles "An exploratory investigation of aspirational consumption at the bottom of the pyramid" and "Despite unethical retail store practices, consumers at the bottom of the pyramid continue to be loyal". Shruti Gupta is a marketing professor at Pennsylvania State University, Abington, USA and Pratish Srivastav is from Ganeshi Lal Aggarwal University, Mathura, India. Shruti Gupta also worked on the article "Brand adoption by BoP retailers" with Saurabh Rawal, who is from the University of Alberta, Edmonton, Canada. 
Although the connection between Tendai Chikweche and Richard Fletcher consists of only two authors, they have published five articles together, these being "Customer relationship management at the base of the pyramid: Myth or reality?", "Family purchase decision making at the bottom of the pyramid", "Franchising at the bottom of the pyramid (BOP): An alternative distribution approach", "Revisiting the marketing mix at the bottom of pyramid (BOP): From theoretical considerations to practical realities" and "Undertaking research at the bottom of the pyramid using qualitative methods: From theoretical considerations to practical realities". Tendai Chikweche and Richard Fletcher are from Western Sydney University, Sydney, Australia.

This analysis shows authors in the four countries that are highlighted in Figure 4 as being those most active in research on the bottom of the pyramid, namely, the United Kingdom, United States, India and Australia.

To analyze the bursts of keywords that occurred in each year of the sample, that is, the topics most related to consumption at the bottom of the pyramid in the analyzed articles, Table 3 lists the 30 main keywords appearing between 2007 and 2018.

Table 3: Keywords with the Most Pronounced Bursts in Publications about the BoP

\begin{tabular}{|c|c|c|c|c|}
\hline \multirow{2}{*}{ Keywords } & \multicolumn{4}{|c|}{ Citation bursts } \\
\hline & Strength & Start & End & $2004-2018$ \\
\hline Mobile Communication & 21.357 & 2007 & 2010 & \\
\hline Diffusion & 15.148 & 2007 & 2012 & \\
\hline Information Technology & 20.822 & 2008 & 2013 & \\
\hline Poverty & 14.284 & 2008 & 2010 & \\
\hline Marketing Strategy & 28.689 & 2008 & 2011 & \\
\hline Globalization & 2.579 & 2008 & 2010 & \\
\hline Emerging Market & 22.966 & 2009 & 2011 & \\
\hline Poverty Alleviation & 31.205 & 2009 & 2012 & \\
\hline Strategy & 17.855 & 2010 & 2012 & \\
\hline Commerce & 15.164 & 2010 & 2013 & \\
\hline Base of the Pyramid & 24.098 & 2010 & 2014 & \\
\hline Subsistence Marketplace & 24.728 & 2010 & 2012 & \\
\hline Innovation & 15.804 & 2010 & 2011 & \\
\hline Bottom of the Pyramid & 60.027 & 2011 & 2012 & \\
\hline Income & 18.793 & 2012 & 2013 & \\
\hline Mobile Telephony & 24.412 & 2013 & 2014 & \\
\hline Developing Country & 17.873 & 2013 & 2015 & - \\
\hline Bangladesh & 19.055 & 2013 & 2015 & $=$ \\
\hline$B O P$ & 16.117 & 2013 & 2014 & $=$ \\
\hline Business & 20.991 & 2014 & 2016 & \\
\hline Bottom & 20.991 & 2014 & 2016 & \\
\hline Sustainable Development & 1.2637 & 2014 & 2016 & \\
\hline Consumption Behavior & 15.199 & 2015 & 2016 & \\
\hline Entrepreneur & 0.8886 & 2015 & 2016 & $=$ \\
\hline Rural India & 15.199 & 2015 & 2016 & $=$ \\
\hline Consumption Behavior & 1.5199 & 2015 & 2016 & \\
\hline Microcredit & 0.8865 & 2015 & 2018 & ב \\
\hline Financial Service & 0.8865 & 2015 & 2018 & \\
\hline Market & 17.546 & 2016 & 2018 & - \\
\hline Management & 0.946 & 2016 & 2018 & - \\
\hline
\end{tabular}

As shown in Table 3, no citation bursts appeared in the early years (2004-2006), with the first bursts occurring in 2007 with the words "mobile communication" and "diffusion." Currently, research related to the market or consumption at the bottom of the pyramid is mainly about microcredit, financial services, market and management. The analysis shows that many studies were conducted in countries such as Bangladesh and India, regions with many poor people.

Figure 6 shows the network with the most cited articles in the analyzed sample. For example, Karnani (2007) was the most frequently cited, as in the analysis of Table 1, with 50 citations. Prahalad's book (2005) "The Fortune at the Bottom of the Pyramid: Eradicating Poverty through Profits" is in second place with 39 citations. However, there is some confusion about the year of citation of two works, as Prahalad (2004) and Prahalad (2005) refer to the same book. This makes it the work most cited by articles in the sample, with 69 citations. This book is a point of reference for research on the bottom of the pyramid, which refers to the more than 4 billion people who survive on less than $\$ 2$ per day. The book aims to show that stereotypes of poverty end up hiding the fact that the poor are also conscious entrepreneurs and consumers.

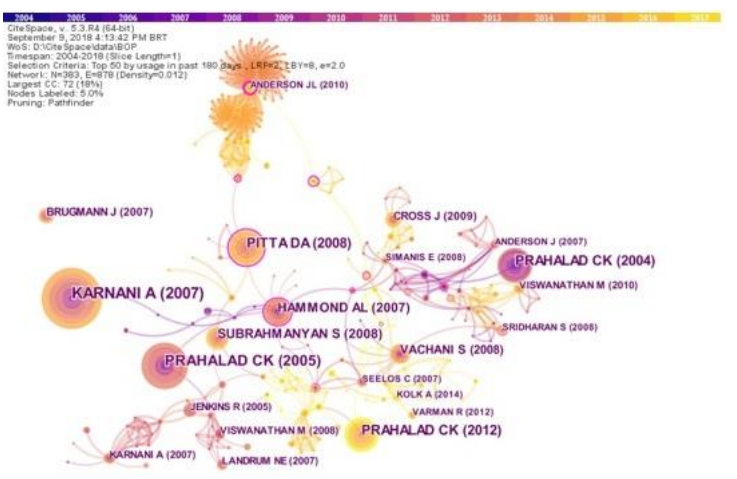

Figure 6. Network of Co-Citations of Works Cited by Articles in the Search (Frequency $>=8$ )

The articles by Prahalad (2012) and Pitta, Guesalaga and Marshall (2008), which also appeared among the most cited in Table 1, appear with 30 and 29 citations, respectively, figuring prominently in the network. Hammond et al.'s study (2007) "The Next 4 Billion: Market Share and Business Strategy at the Base of the Pyramid" also stands out in the network with 23 citations. Like Prahalad's book (2005), the study by Hammond et al. (2007) addresses the majority of the world's population, the 4 billion people who live in relative poverty and constitute the bottom of the pyramid, suggesting important opportunities for them to enter the formal economy, having their needs met and increasing income and productivity.

The CitNetExplorer tool helped visualize and analyze the publication citation networks (Van Eck and Waltman, 2014), as shown in Figure 7. This program makes it possible to identify related publications and the creation of clusters. Publications with more than 10 citations were selected and grouped into three clusters based on their relationships with regard to the subject, that is, those located in the same cluster tend to describe a certain topic in the academic literature. Publications belonging to the same group are shown in the same color.

The first study appearing in the citations network is Hernando de Soto's 2000 book The Mystery of Capital: Why Capitalism Triumphs in the West and Fails Everywhere Else. De Soto argues that capitalism has enriched Western countries, but failed in less developed countries for reasons such as the fact that individuals do not hold legal title to their property and onerous legal restrictions to the creation of businesses affect their proper functioning. Most developing countries do not have an efficient and reliable way of registering and transferring property ownership. Therefore, citizens cannot convert their property into capital to invest in businesses or use as collateral for loans. 
It can also be observed that Kolk et al. (2014) account for most of the publications in the network, with a total of 20 connections. This study consists of a systematic review of the literature covering articles from 2000 to 2009 for the purpose of showing how the concept of the bottom of the pyramid evolved over this period. The article does not perform a traditional analysis of the literature, but concentrates on the set of articles that clearly built on Prahalad's original concept.

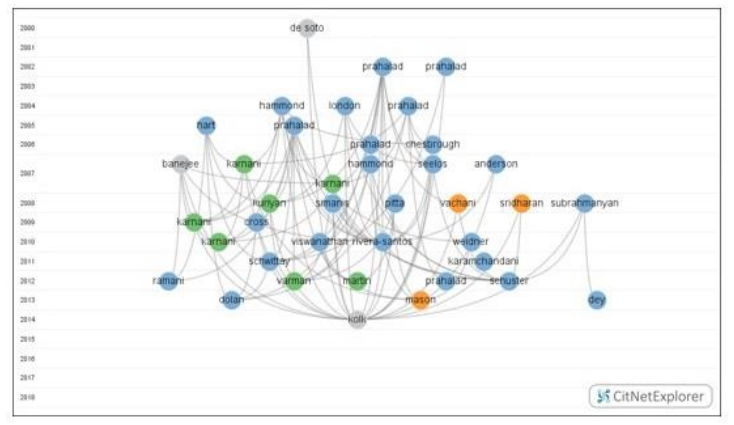

Figure 7. Publication citations networks (frequency $>=10$ )

The blue cluster addresses Prahalad's ideas about businesses investing at the bottom of the pyramid, a large and potentially lucrative market, offering products at lower prices and contributing to reducing poverty, with the idea of being both socially responsible and profitable. Many articles provide guidance about the challenges encountered and how companies can adapt their strategies to sell to the BoP market.

The articles appearing in green in Figure 7 criticize Prahalad's idea (2005) about "doing well by doing good," pointing out the challenge of being profitable while fostering social development and stating that this is fundamentally misleading. Critics claim it is a dangerous illusion to believe that companies have the welfare of low-income people at heart and that this romanticized view harms vulnerable poor consumers. Furthermore, even if the segment is seen as a viable market, poverty has not been reduced. The idea advocated by Karnani (2007) is that, the only way to increase income and reduce poverty is to see the poor as producers rather than as consumers.

The orange cluster shows articles that view individuals at the bottom of the pyramid as both consumers and producers or in an even more holistic perspective, extending beyond these two roles. The publications shown in gray did not fit into any of these three clusters.

Table 4 shows the earliest and most cited publication in each cluster. The citation score represents the number of times a publication is cited within the analyzed network, that is, the number of citations received from other publications about the "bottom of the pyramid" and "consum*" or "market*" in the Web of Science database.
Table 4: Earliest and Most Cited Publication in Each Cluster of the Citations Network

\begin{tabular}{|c|c|c|c|c|c|}
\hline Cluster & $\begin{array}{l}\text { Type of } \\
\text { study }\end{array}$ & Authors & Title & Journal & $\begin{array}{c}\begin{array}{c}\text { Citation } \\
\text { Score }\end{array} \\
\end{array}$ \\
\hline \multirow[b]{2}{*}{ Blue } & Earliest & $\begin{array}{l}\text { Prahalad and Hart } \\
\text { (2002) }\end{array}$ & $\begin{array}{l}\text { The fortune at the bottom of the } \\
\text { pyramid }\end{array}$ & Strategy + Business & 18 \\
\hline & Most cited & $\begin{array}{c}\text { Prahalad and } \\
\text { Hammond (2002) }\end{array}$ & Serving the world's poor, profitably & $\begin{array}{l}\text { Harvard Business } \\
\text { Review }\end{array}$ & 44 \\
\hline \multirow{2}{*}{ Green } & Earliest & Karnani (2007a) & $\begin{array}{l}\text { Doing well by doing good - Case study: } \\
\text { 'Fair \& Lovely' whitening cream }\end{array}$ & $\begin{array}{l}\text { Strategic } \\
\text { Management } \\
\text { Journal }\end{array}$ & 10 \\
\hline & Most cited & Karnani (2007b) & $\begin{array}{l}\text { The mirage of marketing to the bottom } \\
\text { of the pryamid. How the private sector } \\
\text { can help alleviate poverty }\end{array}$ & $\begin{array}{l}\text { California } \\
\text { Management } \\
\text { Review }\end{array}$ & 32 \\
\hline \multirow{3}{*}{ Orange } & Earliest & $\begin{array}{l}\text { Vachani and } \\
\text { Smith (2008) }\end{array}$ & $\begin{array}{l}\text { Socially responsible distribution: } \\
\text { distribution strategies for reaching the } \\
\text { bottom of the pyramid }\end{array}$ & $\begin{array}{c}\text { California } \\
\text { Management } \\
\text { Review } \\
\end{array}$ & 11 \\
\hline & \multirow{2}{*}{ Most cited- } & $\begin{array}{l}\text { Vachani and } \\
\text { Smith (2008) }\end{array}$ & $\begin{array}{l}\text { Socially responsible distribution: } \\
\text { distribution strategies for reaching the } \\
\text { bottom of the pyramid }\end{array}$ & $\begin{array}{c}\text { California } \\
\text { Management } \\
\text { Review } \\
\end{array}$ & 11 \\
\hline & & $\begin{array}{l}\text { Sridharan and } \\
\text { Viswanathan } \\
\text { (2008) }\end{array}$ & $\begin{array}{l}\text { Marketing in subsistence marketplaces: } \\
\text { consumption and entrepreneurship in a } \\
\text { South Indian context }\end{array}$ & $\begin{array}{l}\text { Journal of } \\
\text { Consumer } \\
\text { Marketing }\end{array}$ & 11 \\
\hline
\end{tabular}

It can be seen that, the publication with the highest citation score in the network is Prahalad and Hammond's article (2002) "Serving the world's poor, profitably" found in the table.

\section{Conclusion and Recommendations}

This article reviews the state of the literature on consumption at the bottom of the pyramid and summarizes suggestions for future research made by articles published in 2017. Two leading databases, Scopus and the Web of Science, were used to conduct research on important international and Brazilian journals. The review identified the most frequently cited articles, including Karnani (2007) Seelos and Mair (2007) and Prahalad (2012), and the journals that published the greatest number of articles, such as the Journal of Consumer Marketing and Marketing Theory. A world map illustrates countries with highest publications number in the field, including the United States, United Kingdom, India and Australia.

Keywords were also analyzed, showing that the terms mobile communication and diffusion began gaining prominence in 2007, with current focuses on microcredit, financial services, markets and management. A co-citations network showed that Karnani's (2007) article and Prahalad's (2005) book appeared prominently. Finally, a table showing a summary of the suggestions for future research made by articles published in 2017 . The suggestions were analyzed to identify research gaps with the aim of encouraging other interested researchers to explore the topics discussed in this review, as they are highly relevant to the study of consumption at the bottom of the pyramid and to improving the living standards of this segment of the population.

Similar to any research, this article has its limitations. Because it worked with two databases, the study was limited in its ability to conduct joint analyses. For example, the CitNetExplorer program used to map citations employs only data from the Web of Science. Furthermore, this review used only articles published in journals. Although it is common to include only these articles in reviews, a number of studies published in conference proceedings address interesting topics that can contribute to the study of the subject. Also, important scholars studying the bottom of the pyramid, including Prahalad, have published books that are important references in this field but were not considered in this study. Another point is that, this study concentrated only 
on papers that used the bottom of the pyramid concept due to the need to dig deeply into the subject.

To show future research trends, the articles published in 2017 were analyzed with regard to their authors' suggestions for further research to identify gaps to be filled by future studies. It was decided to limit this analysis to articles published in 2017 as this was the last full year included in the study. Of the 26 articles published that year, two were not accessible and ten did not make any recommendations for future research. Based on 12 of the 26 articles analyzed, Figure 8 shows four of the most commonly occurring themes. The themes are: (1) Increasing the knowledge on the bottom of the pyramid; (2) Businesses and the bottom of the pyramid; (3) Loyalty/Satisfaction; and (4) Brand, product and retail. These were subdivided into 13 topics and connected according to the similarity of their proposals. The authors also suggested that, future research be conducted with larger samples and different methodologies than the ones they had used.

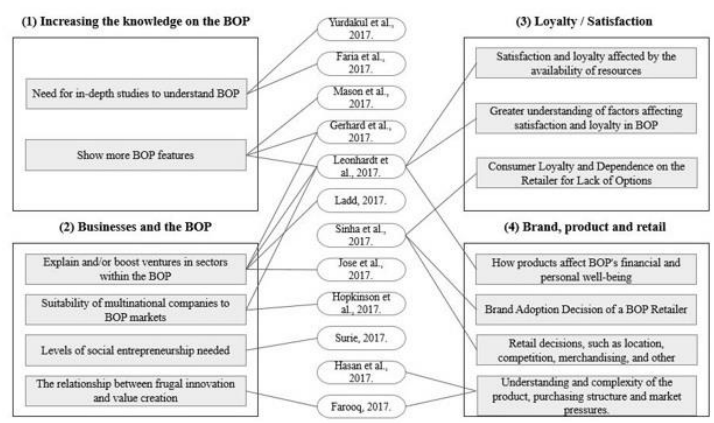

Figure 8. Map of Directions for Future Research on the Bottom of the Pyramid

The first theme includes the need for more indepth studies to better characterize and understand the bottom of the pyramid, as well as to better understand poverty and its concept through the study of new contexts that have been neglected (Yurdakul et al., 2017; Faria and Hemais, 2017; Mason and Chakrabarti, 2017; Gerhard et al., 2017; Leonhardt and Chu, 2017). The second trend is projects that aim to explain or boost investment at the bottom of the pyramid, such as fairs, microloans and multinational activities. This theme also includes the necessary levels of social entrepreneurship and the relationship between the frugal economy and value generation (Gerhard et al., 2017; Ladd, 2017; Leonhardt and Chu, 2017; Jose and Chacko, 2017; Hopkinson and Aman, 2017; Surie, 2017; Farooq, 2017).

The third theme is related to better understanding loyalty and satisfaction, how these are affected by resource availability and how consumers' loyalty to a supplier can be due simply to a lack of alternatives (Leonhardt and Chu, 2017; Sinha et al., 2017). The fourth theme addresses brand, product and retail, discussing how products or services affect both personal and financial well-being at the bottom of the pyramid, such as the use of online banking, the understanding and complexity of the product, purchasing structure, market pressures and retailers' decisions about adopting brands and retail (Leonhardt and Chu, 2017; Sinha et al., 2017; Hasan et al., 2017; Farooq, 2017). Suggestions are also made for long-term studies to assess consumer behavior over time and qualitative research such as ethnographies. It is hoped that this summary will contribute to future research on consumption at the bottom of the pyramid, with recent suggestions for studies that have probably not yet been undertaken.

\section{References}

Agarwal, N. et al. (2017), A systematic literature review of constraint-based innovations: state of the art and future perspectives, IEEE Transactions on Engineering Management, vol. 64 n. 1, pp. 315.

Ahmad, P. S. et al. (2004), Case Study: Hindustan Lever Limited and marketing to the poorest of the poor, International Journal of Entrepreneurship and Innovation Management, vol. 4 n. 5, pp. 495-511.

Ansari, S. et al. (2012), Impact at the 'bottom of the pyramid': The role of social capital in capability development and community empowerment, Journal of Management Studies, vol. 49 n. 4, pp. 813-842.

Bittar, M. et al. (2011), Produção científica em dois periódicos da área de educação, Avaliação: Revista da Avaliação da Educação Superior, vol. 16 n. 3, pp. 655-674.

Bojović, S. et al. (2014), An overview of forestry journals in the period 2006-2010 as basis for ascertaining research trends, Scientometrics, vol. 98 n. 2, pp. 1331-1346.

Chen, C. (2006), CiteSpace II: Detecting and visualizing emerging trends and transient patterns in scientific literature, Journal of the American Society for information Science and Technology, vol. 57 n. 3, pp. 359-377.

Chen, C. (2004), Searching for intellectual turning points: Progressive knowledge domain visualization, Proceedings of the National Academy of Sciences, vol. 101 n. 1, pp. 53035310.

Chen, Y. and Wu, C. (2017), The hot spot transformation in the research evolution of maker, Scientometrics, vol. 113 n. 3, pp. 1307-1324.

Cooney, K. and Williams Shanks, T. R. (2010), New approaches to old problems: Market-based strategies for poverty alleviation, Social Service Review, vol. 84 n. 1, pp. 29-55.

De Soto, H. (2000), The mystery of capital: Why capitalism triumphs in the West and fails everywhere else, Basic Civitas Books.

Faria, A. and Hemais, M. (2017), Rethinking the bottom of the pyramid: A critical perspective from an emerging economy, Marketing Theory, vol. 17 n. 3, pp. 271-287. 
Farooq, R. (2017), A conceptual model of frugal innovation: is environmental munificence a missing link?, International Journal of Innovation Science, vol. 9 n. 4, pp. 320-334.

Filser, L. D. et al. (2017), State of research and future research tendencies in lean healthcare: a bibliometric analysis, Scientometrics, vol. 112 n. 2 , pp. $799-816$

Gerhard, F. et al. (2017), Exploring utilitarian and hedonic aspects of consumption at the bottom of pyramid, Revista Brasileira de Marketing, vol. 16 n. 3, pp. 268-280.

Hammond, A. L. et al. (2007), The next 4 billion, Innovations: Technology, Governance, Globalization, vol. 2 n. 1-2, pp. 147-158.

Hasan, M. R. et al. (2017), Visual cues and innovation adoption among bottom of the pyramid consumers, Qualitative Market Research: An International Journal, vol. 20 n. 2, pp. 147-157.

Hayashi, M. C. P. I. (2013), Afinidades eletivas entre a cientometria e os estudos sociais da ciência.

Hopkinson, G. and Aman, A. (2017), Women entrepreneurs: How power operates in bottom of the pyramid-marketing discourse, Marketing Theory, vol. 17 n. 3, pp. 305-321.

Jose, S. and Chacko, J. (2017), Sustainable development of microfinance customers: An empirical investigation based on India, Journal of Enterprise Information Management, vol. $30 \mathrm{n}$. 1, pp. 49-64.

Karnani, A. (2007), The mirage of marketing to the bottom of the pyramid: How the private sector can help alleviate poverty, California management review, vol. 49 n. 4, pp. 90-111.

Kolk, A. et al. (2014), Reviewing a decade of research on the "base/bottom of the pyramid"(BOP) concept, Business \& Society, vol. 53 n. 3, pp. 338-377.

Ladd, T. (2017), Business models at the bottom of the pyramid: leveraging context in undeveloped markets, The International Journal of Entrepreneurship and Innovation, vol. 18 n. 1, pp. 57-64.

Leonhardt, J. M. and Chu, R. (2017), Online banking adoption at the bottom of the pyramid: a survey of Chinese migrant workers, International Journal of Emerging Markets, vol. 12 n. 4, pp. 742-752.

Mason, K. and Chakrabarti, R. (2017), The role of proximity in business model design: Making business models work for those at the bottom of the pyramid, Industrial Marketing Management, vol. 61, pp. 67-80.
Nogami, V. K. C. and Pacagnan, M. N. (2012), Produção Acadêmica sobre o Consumo na Base da Pirâmide na Área de Marketing: uma Pesquisa Bibliométrica, Revista ADM. MADE, vol. 15 n. 3, pp. 100-122.

Pitta, D. A. et al. (2008), The quest for the fortune at the bottom of the pyramid: potential and challenges, Journal of Consumer Marketing, vol. 25 n. 7, pp. 393-401.

Prado, J. W. et al. (2016), Multivariate analysis of credit risk and bankruptcy research data: a bibliometric study involving different knowledge fields (19682014), Scientometrics, vol. 106 n. 3, pp. $1007-$ 1029.

Prahalad, C. K. (2005), The Fortune at the Bottom of the Pyramid, Pearson Education.

Prahalad, C. K. (2012), Bottom of the Pyramid as a Source of Breakthrough Innovations, Journal of Product Innovation Management, vol. $29 \mathrm{n}$. 1, pp. 6-12.

Prahalad, C. K. and Hammond, A. (2002), Serving the world's poor, profitably, Harvard business review, vol. 80 n. 9, pp. 48-59.

Prahalad, C. K. and Hart, S. L. (2002), The fortune at the bottom of the pyramid, Strategy \& Business.

Rocha, A. D. and Silva, J. F. (2008), Inclusão social e marketing na base da pirâmide: uma agenda de pesquisa, RAE-eletrônica, vol. 7 n. 2.

Seelos, C. and Mair, J. (2007), Profitable business models and market creation in the context of deep poverty: A strategic view, Academy of management perspectives, vol. 21 n. 4, pp. 4963.

Sinha, P. K. et al. (2017), Brand adoption by BoP retailers, Qualitative Market Research: An International Journal, vol. 20 n. 2, pp. 181-207.

Surie, G. (2017), Creating the innovation ecosystem for renewable energy via social entrepreneurship: Insights from India, Technological Forecasting and Social Change, vol. 121, pp. 184-195.

Taşkın, Z. and Al, U. (2014), Standardization problem of author affiliations in citation indexes, Scientometrics, vol. 98 n.1, pp. 347-368.

Van Eck, N. J. and Waltman, L. (2014), CitNetExplorer: A new software tool for analyzing and visualizing citation networks, Journal of Informetrics, vol. 8 n. 4, pp. 802-823.

Yurdakul, D. et al. (2017), Redefining the bottom of the pyramid from a marketing perspective, Marketing Theory, vol. 17 n. 3, pp. 289-303. 